\title{
GeoChip-based analysis of the microbial community functional structures in simultaneous desulfurization and denitrification process
}

\author{
Hao $\mathrm{Yu}^{1,2}$, Chuan Chen ${ }^{2, *}$, Jincai $\mathrm{Ma}^{3}$, Wenzong Liu ${ }^{4}$, Jizhong Zhou ${ }^{5}$, Duu-Jong Lee ${ }^{6}$, \\ Nanqi Ren ${ }^{2}$, Aijie Wang ${ }^{2,4, *}$ \\ 1. School of Environmental Science and Engineering, Liaoning Technical University, Fuxin 123000, China. Email: micro_yh@126.com \\ 2. State Key Laboratory of Urban Water Resource and Environment, Harbin Institute of Technology, Harbin 150090, China \\ 3. Biosciences and Biotechnology Division, Lawrence Livermore National Laboratory, Livermore, CA 94550, USA \\ 4. Research Center for Eco-Environmental Sciences, Chinese Academy of Sciences, Beijing 100085, China \\ 5. Institute for Environmental Genomics, Department of Botany and Microbiology, University of Oklahoma, Norman, OK 73019, USA \\ 6. Department of Chemical Engineering, Taiwan University, Taipei 10617, Chinese Taipei
}

\section{A R T I C L E I N F O}

\section{Article history:}

Received 19 August 2013

Revised 2 December 2013

Accepted 31 December 2013

Available online 10 June 2014

Keywords:

Expanded granular sludge bed

Elemental sulfur recovery

Microbial community

Functional gene array

\begin{abstract}
A B S T R A C T
The elemental sulfur $\left(\mathrm{S}^{9}\right)$ recovery was evaluated in the presence of nitrate in two development models of simultaneous desulfurization and denitrification (SDD) process. At the loading rates of $0.9 \mathrm{~kg} \mathrm{~S} /\left(\mathrm{m}^{3}\right.$.day) for sulfide and $0.4 \mathrm{~kg} \mathrm{~N} /\left(\mathrm{m}^{3}\right.$.day) for nitrate, $S^{0}$ conversion rate was $91.1 \%$ in denitrifying sulfide removal (DSR) model which was higher than in integrated simultaneous desulfurization and denitrification (ISDD) model (25.6\%). A comprehensive analysis of functional diversity, structure and metabolic potential of microbial communities was examined in two models by using functional gene array (GeoChip 2.0). GeoChip data indicated that diversity indices, community structure, and abundance of functional genes were distinct between two models. Diversity indices (Simpson's diversity index $(1 / D)$ and Shannon-Weaver index $\left(H^{\prime}\right)$ ) of all detected genes showed that with elevated influent loading rate, the functional diversity decreased in ISDD model but increased in DSR model. In contrast to ISDD model, the overall abundance of dsr genes was lower in DSR model, while some functional genes targeting from nitrate-reducing sulfide-oxidizing bacteria (NR-SOB), such as Thiobacillus denitrificans, Sulfurimonas denitrificans, and Paracoccus pantotrophus were more abundant in DSR model which were highly associated with the change of $S^{0}$ conversion rate obtained in two models. The results obtained in this study provide additional insights into the microbial metabolic mechanisms involved in ISDD and DSR models, which in turn will improve the overall performance of SDD process.
\end{abstract}

C 2014 The Research Center for Eco-Environmental Sciences, Chinese Academy of Sciences.

Published by Elsevier B.V.

\section{Introduction}

There is an increasing concern that numerous industries generate and release significant amount of wastewater containing high level

\footnotetext{
* Corresponding authors. E-mails: echo110244@126.com (Chuan Chen); waj0578@hit.edu.cn (Aijie Wang).
}

of sulfate and nitrate. Under anaerobic conditions, sulfate can be reduced to sulfide by sulfate-reducing bacteria (SRB) which may result in severe corrosive damage to sewer, and toxic effect on ecosystems, and human health (Garcia-de-Lomas et al., 2007; Rattanapan et al., 2009; Wiessner et al., 2005). In order to solve the problems, biological SDD process system has been proposed (Wang et al., 2005), and it seems to be a promising strategy since it is 
environmentally friendly and cost-effective. Sulfide is expected to be eliminated via partial oxidation to $S^{0}$ by NR-SOB using nitrate as the electron acceptor, and nitrate is expected to be reduced to nitrogen gas by both heterotrophic denitrifiers and NR-SOB (De Gusseme et al., 2009). Furthermore, the $S^{0}$ can be reused as fertilizer or as the raw material after separation (Celis-García et al., 2008; Sahinkaya et al., 2011).

Wang et al. (2005) used an autotrophic bacterium Thiobacillus denitrificans to remove sulfide and nitrate. A total of $75 \%$ sulfide was oxidized to $\mathrm{S}^{0}$ with sulfide influent concentration of $300 \mathrm{mg} / \mathrm{L}$. Reyes-Avila et al. (2004) obtained nitrogen, sulfide, and COD simultaneous removal in a continuous stirred tank reactor (CSTR) at a loading rate of $0.2 \mathrm{~kg} \mathrm{~N} /\left(\mathrm{m}^{3} \cdot\right.$ day $), 0.294 \mathrm{~kg} \mathrm{~S} /\left(\mathrm{m}^{3} \cdot\right.$ day $)$ and $0.29 \mathrm{~kg} \mathrm{C} /\left(\mathrm{m}^{3}\right.$. day), respectively. These experiments well proved the feasibility of SDD process. Recently, with the development of SDD process, two conceptual models were proposed (Chen et al., 2008a, 2008b, 2008c, 2009): (1) DSR model that focuses on sulfide and nitrate removal and the key functional species that are heterotrophic denitrifiers and NR-SOB; and (2) ISDD model that integrates sulfate reducing process and DSR process into one bioreactor and key functional species that are SRB, heterotrophic denitrifiers and NR-SOB. Chen et al. (2008a) observed the performance of ISDD model in an expanded granular sludge bed (EGSB) reactor. Although the removal efficiencies of sulfate and nitrate were $78 \%,>99 \%$ when sulfate loading rate was $2.1 \mathrm{~kg} /\left(\mathrm{m}^{3} /\right.$ day) and nitrate loading rate was $1.7 \mathrm{~kg} /\left(\mathrm{m}^{3} /\right.$ day), the conversion efficiency of $\mathrm{S}^{0}$ was considerably low $(10 \%-40 \%)$. To date, the mechanism for low $S^{0}$ conversion efficiency of ISDD model was still unclear. Subsequently, the performance of DSR model was evaluated in a different EGSB reactor (Chen et al., 2009). Satisfied sulfide removal efficiency $(97 \%)$, nitrate removal efficiency (97\%) and $S^{0}$ conversion efficiency (>92\%) were obtained.

Although ISDD and DSR models have been investigated, a comprehensive comparison between two models is lacking. Most importantly, a complete understanding of overall functional diversity, metabolic mechanism of functional species and community compositions is still missing. This is because that the microbial communities were studied by conventional molecular techniques, such as singlestrand conformation polymorphism (SSCP) and denaturing gradient gel electrophoresis (DGGE) (Chen et al., 2008a, 2008b) which are low throughput, low resolution, hard to quantify, and provide limited functional information (Zhou et al., 2010). A better understanding of the microbial processes involved in the removal of $\mathrm{S}$ and $\mathrm{N}$ is valuable since it could help diagnose and correct general problems of ISDD and DSR models, and therefore can improve the overall performance of bioreactor especially in terms of $S^{0}$ recovery efficiency.

GeoChip-based metagenomics technology has emerged as a novel high throughput tool that provides more insights into structure, composition and potential activity of microbial communities in both artificial and natural environments. To date, GeoChip has been widely used to study microbial communities in samples from various sources, which include soil, oil fields, water, marine sediments, and bioreactor systems (Bai et al., 2013; Liang et al., 2009; Liu et al., 2010; Van Nostrand et al., 2009; Waldron et al., 2009; Wu et al., 2008; Zhou et al., 2008, 2012). The aim of this work was to evaluate the $S^{0}$ recovery rates and nitrate reduction efficiencies, and to reveal the metabolic diversity, structure, abundance of microbial communities in ISDD and DSR models, which will reveal the mechanisms of low $S^{0}$ conversion rate. Continuous lab-scale experiments were conducted for the ISDD model and two similar EGSB reactors for the DSR model. The microbial community structures were characterized by GeoChip.

\section{Materials and methods}

\subsection{Reactor setup and working conditions}

Experiments were conducted by Plexiglas EGSB reactor modified by Chen et al. (2008a) with a height of $200 \mathrm{~cm}$, a diameter of
$80 \mathrm{~mm}$ and a working volume of $4.0 \mathrm{~L}$. The thermal state of reactor was $(28 \pm 1)^{\circ} \mathrm{C}$. The initial granules for two models were obtained from EGSB reactor (Chen et al., 2008a). As suggested by Chen et al. (2008a), the sulfate and lactate were contained in influent for acclimation of SRB, and then nitrate was added in reactor for acclimation of denitrifiers. The initial sulfate-laden synthetic wastewater was fed into ISDD model containing $1000 \mathrm{mg} / \mathrm{L} \mathrm{SO}_{4}^{2-}$ and $1000 \mathrm{mg} / \mathrm{L}$ lactate (2000 mg/L COD). The pH was controlled by using bicarbonate with $(8.0 \pm 0.3)$. The micronutrients were fed to wastewater as previously reported (Chen et al., 2008a). In DSR model, EGSB reactor was started with sulfide-laden medium with the following composition: $200 \mathrm{mg} / \mathrm{L} \mathrm{S} \mathrm{S}^{2-}, 400 \mathrm{mg} / \mathrm{L} \mathrm{NO}_{3}^{-}, 210 \mathrm{mg} / \mathrm{L}$ acetate, $1500 \mathrm{mg} / \mathrm{L}$ $\mathrm{NaHCO}_{3}, 50 \mathrm{mg} / \mathrm{L} \mathrm{K}_{2} \mathrm{HPO}_{4} \cdot 3 \mathrm{H}_{2} \mathrm{O}$ and $50 \mathrm{mg} / \mathrm{L} \mathrm{NH} \mathrm{Nl}_{4}$. The concentrations of nitrate, nitrite, sulfide, sulfate, and thiosulfate were measured using the methods as previously reported (Chen et al., 2008b).

The wastewater characterization was done for ISDD model and DSR model. Each model of test contained three periods as listed in Table 1: low loading rate period; medium loading rate period; and high loading rate period. The $\mathrm{S}^{0}$ production was calculated by the following equation (de Graaff et al., 2012):

$$
\left[\mathrm{S}^{0}\right]=[\text { influent } \mathrm{S}]-\left[\mathrm{SO}_{4}^{2-}\right]-2 \times\left[\mathrm{S}_{2} \mathrm{O}_{3}^{2-}\right]-\left[\mathrm{HS}^{-}\right] \text {. }
$$

\subsection{DNA extraction, amplification, labeling and hybridization}

Two sludge samples were collected from ISDD model at operational days 25 and 75 with sample ID being labeled as I1 and I2, respectively. Three sludge samples were collected from DSR model at operational days 17, 29 and 42 with sample ID being labeled as D1, D2 and D3, respectively.

The sludge samples were saved in sterile plastic bags under $-20^{\circ} \mathrm{C}$ freezer before DNA extraction. Genomic DNA was extracted from granular sludge by freeze-grinding method as previously described (Zhou et al., 1996). Template DNA (100 ng) from each sample was amplified by using a modified Templiphi kit (GE Healthcare, USA) (Wu et al., 2008). The amplified DNA was labeled using Cy5 fluorescent dye (GE Healthcare, USA) with random primer and the labeled DNA was purified by QIAquick PCR purification column (Qiagen, USA) using protocols described previously (Wu et al., 2008). The purified DNA was dried and resuspended in $130 \mu \mathrm{L}$ hybridization solution (Wu et al., 2006). Hybridization process was carried out in a Tecan HS 4800 Pro Hybridization Station (Tecan US, USA) at $42^{\circ} \mathrm{C}$ for $10 \mathrm{hr}$.

\subsection{Data analysis}

All microarrays slides were scanned by a ScanArray 500 microarray scanner (PerkinElmer, USA) at a laser power of $95 \%$, photomultiplier tube (PMT) gain of $75 \%$ and analyzed with ImaGene 6.0 (Biodiscovery, USA). Poor spots were removed with signal-to-noise ratio (SNR) $(\mathrm{SNR}=$ (signal intensity background) / standard deviation of background) $<2.0$ and standard deviation (SD) $>2.0$. Diversity of functional genes was calculated by Simpson's reciprocal index (1/D) and Shannon-Weaver index $\left(H^{\prime}\right)$ using R (v.2.12.0; http://www.rproject.org/). Principal component analysis (PCA) was performed 
Table 1-Operational data and reactor performance of two models ISDD: integrated simultaneous desulfurization and denitrification; DSR: denitrifying sulfide removal. Low: low loading rate period; medium: medium loading rate period; high: high loading rate period. "-": not added in influent wastewater.

\begin{tabular}{|c|c|c|c|c|c|c|c|c|c|}
\hline \multirow[t]{2}{*}{ Model } & \multirow[t]{2}{*}{ Time (day) } & \multirow[t]{2}{*}{ Period } & \multicolumn{3}{|c|}{$\begin{array}{l}\text { Influent loading rate } \\
\left(\mathrm{kg} /\left(\mathrm{m}^{3} \cdot \text { day }\right)\right)\end{array}$} & \multicolumn{3}{|c|}{ Removal efficiency (\%) ${ }^{*}$} & \multirow[t]{2}{*}{$\mathrm{S}^{0}$ conversion $(\%)^{*}$} \\
\hline & & & $\mathrm{SO}_{4}^{2-}-\mathrm{S}$ & $S^{2-}-S$ & $\mathrm{NO}_{3}^{-}-\mathrm{N}$ & $\mathrm{SO}_{4}^{2-}$ & $\mathrm{S}^{2-}$ & $\mathrm{NO}_{3}^{-}$ & \\
\hline \multirow[t]{3}{*}{ ISDD } & $1-10$ & Low & 0.30 & - & 0 & $58.2 \pm 2.3$ & - & 0 & $13.3 \pm 2.6$ \\
\hline & $11-26$ & Medium & 0.45 & - & 0.20 & $83.2 \pm 1.6$ & - & $96.5 \pm 1.5$ & $20.0 \pm 2.2$ \\
\hline & $27-76$ & High & 0.90 & - & 0.40 & $75.5 \pm 1.4$ & - & 100 & $25.6 \pm 1.6$ \\
\hline \multirow[t]{3}{*}{ DSR } & $1-18$ & Low & - & 0.22 & 0.10 & - & $53.4 \pm 2.1$ & 100 & $50.0 \pm 2.4$ \\
\hline & $19-30$ & Medium & - & 0.45 & 0.20 & - & $97.3 \pm 1.2$ & 100 & $88.9 \pm 1.8$ \\
\hline & $31-43$ & High & - & 0.90 & 0.40 & - & $97.5 \pm 1.3$ & 100 & $91.1 \pm 1.5$ \\
\hline
\end{tabular}

* All data are presented as mean \pm standard deviation. These data are calculated with the samples collected from the last five time points of each period.

by $\mathrm{R}$ software as well. Hierarchical cluster analysis was performed using algorithm Cluster (http://rana.stanford.edu) and visualized using TREEVIEW (http://rana.stanford.edu/).

\section{Results}

\subsection{Reactor performance}

In ISDD model, the initial synthetic wastewater was introduced into EGSB reactor at a loading of $0.3 \mathrm{~kg} \mathrm{~S} /\left(\mathrm{m}^{3}\right.$. day) for sulfate. The sulfate removal efficiency reached approximately $58.2 \%$. In medial loading rate period (11-26 days), nitrate was added at a loading of $0.2 \mathrm{~kg} \mathrm{~N} /\left(\mathrm{m}^{3}\right.$.day) to the reactor, and influent of sulfur loading rate was increased to $0.45 \mathrm{~kg} /\left(\mathrm{m}^{3}\right.$.day). The nitrate and sulfate removal efficiency was $96.5 \%$ and $83.2 \%$, respectively. Then, the loading rates were further increased to $0.9 \mathrm{~kg} \mathrm{~S} /\left(\mathrm{m}^{3}\right.$.day) and $0.4 \mathrm{~kg} \mathrm{~N} /\left(\mathrm{m}^{3}\right.$. day) in high loading rate period (27-76 days). The nitrate was completely removed at this period, while sulfate removal efficiency was slightly decreased to $75.5 \%$.

In DSR model, bioreactor was fed with sulfide-laden wastewater at the initial loading rates of $0.22 \mathrm{~kg} \mathrm{~S} /\left(\mathrm{m}^{3} \cdot\right.$ day) for sulfide and $0.1 \mathrm{~kg} \mathrm{~N} /\left(\mathrm{m}^{3}\right.$.day) of nitrate. During last two periods, the levels of sulfur loading rate and $\mathrm{NO}_{3}^{-}-\mathrm{N}$ loading rate in influent wastewater were similar with these periods in ISDD model. However, high removal efficiency of sulfide was maintained in DSR model at these two periods $(97.3 \%$ and $97.5 \%$ ). Additionally, nitrate was completely removed in DSR model. Most importantly, the $\mathrm{S}^{0}$ conversion rate reached 91.1\% in high loading rate period which was much higher than all periods in ISDD model $(\leq 25.6 \%)$. Moreover, high concentration of sulfide (>150 mg/L) was detected in effluent water at last two periods of ISDD model, indicating that the sulfide oxidation process might be relatively weak in this model.

\subsection{Functional gene diversity in two models}

The variations of microbial functional diversity were measured by the number of detected genes and diversity indices (Fig. 1). A total of 1581, 423, 662, 671 and 912 genes were detected in I1, I2, D1, D2, and D3, respectively. The richness of functional genes between each sample is: I1 > D3 > D2 > D1 > I2. Similar results were obtained in both Simpson's diversity index $(1 / D)$ and
Shannon-Weaver index $\left(H^{\prime}\right)$. Interestingly, different trends were observed in two models with the increasing of loading rate. The richness and diversity indices decreased sharply in ISDD model $(\mathrm{I} 1 \rightarrow \mathrm{I} 2)$, while they increased in DSR model (D1 $\rightarrow$ D3). In the last period of two models, the influent loading rates were maintained at same level, but their species diversity was varied. Higher species diversity was observed in DSR model (D3), while it was lower in ISDD model (I2).

To characterize the microbial community structures of two models, PCA was performed based on all detected functional genes. As shown in Fig. 2, samples collected from two operational models were separated well. This suggests that initial operational models have a clear effect on shaping community structure. Furthermore, even in the same model, the functional community structure was different in each loading rate period, especially between medium and high loading rate period.

\subsection{Change of functional gene abundance in two models}

The abundance of functional gene groups was presented in Fig. 3. Among five samples, a total of 52 genes (narG, nirK, nirS,

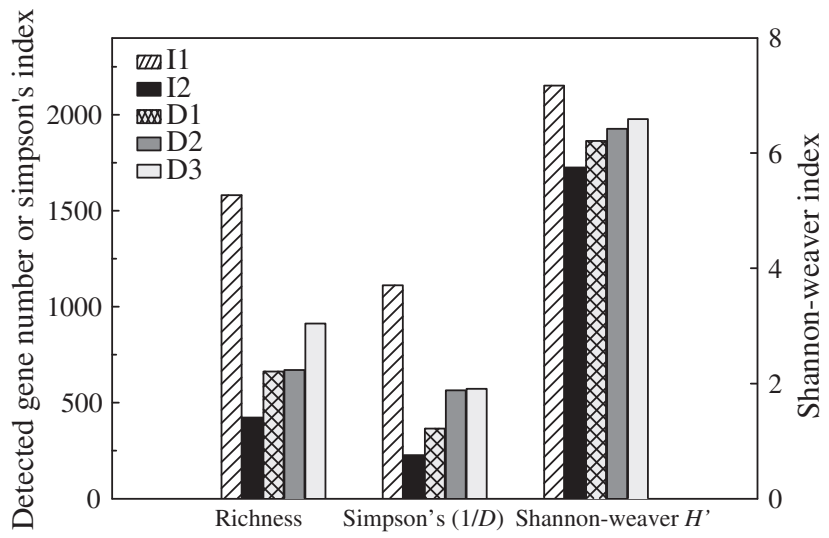

Fig. 1 - Diversity indices and detected gene number for each sample. I1, and 12 represent the sample collected from medium and high loading rate period of ISDD model, respectively; D1, D2, and D3 represent the sample collected from low, medium and high loading rate periods of DSR model, respectively. 
norB and nosZ) sequences for denitrification process, $63 \mathrm{dsr}$ gene (dsr $A, d s r B)$ sequences for sulfate-reducing process, and 7 gene ( $\mathrm{mcr}, \mathrm{mcr} A, \mathrm{mcrG}$ ) sequences for methane generation process were detected. Different patterns were observed from each functional gene category. High abundance of denitrification genes was observed in I2 and D3 collected from high loading rate period. The $d s r$ genes, which serve as indicators of SRB, have relatively higher abundance in the samples from ISDD model and lower abundance in the samples from DSR model. In contrast to other functional gene categories, the abundance of methane producing genes has relatively lower level, and only a total of 7 genes were detected across 5 samples. In addition, only a trace amount of methane gas was detected (data not shown), indicating that the methane production in this system is considerably weak.

\subsection{Analysis of individual function gene categories and species in two models}

In order to gain further insights into functional gene categories, $d s r$ genes and denitrification genes were analyzed by hierarchical clustering. As shown in Fig. 4, the samples from same model were clustered together, i.e., I1 and I2 (ISDD), and D1, D2, and D3 (DSR), which probably represented the difference of SRB community structures in two operational models. The overall dsr genes detected were clustered into two groups: group 1 (17 genes) and group 2 (46 genes) (Fig. 4). Dramatic difference between two models was observed in group 1 . Almost all the genes were detected and have relative high abundance in ISDD model. On the contrary, they were low in DSR model, and 9 of them were below detectable threshold in DSR model, including 3 dsrA genes from Desulfobotulus sapovorans, Desulfobulbus propionicus, and Desulfonema limicola, 1 dsrA gene from uncultured SRB, 3 dsrB genes from Desulfatibacillum aliphaticivorans, Desulforhopalus singaporensis, and Desulfovibrio sp. P1B2 and 2 dsrB genes from uncultured SRB. These species were reported as key SRB in activated sludge, and were also detected in marine and even in saline lake (Cravo-Laureau, 2004; Klepac-Ceraj et al., 2012; Manz et al., 1998). It is likely that some species of SRB have considerably low metabolism activity in DSR model (Figs. 3 and 4).

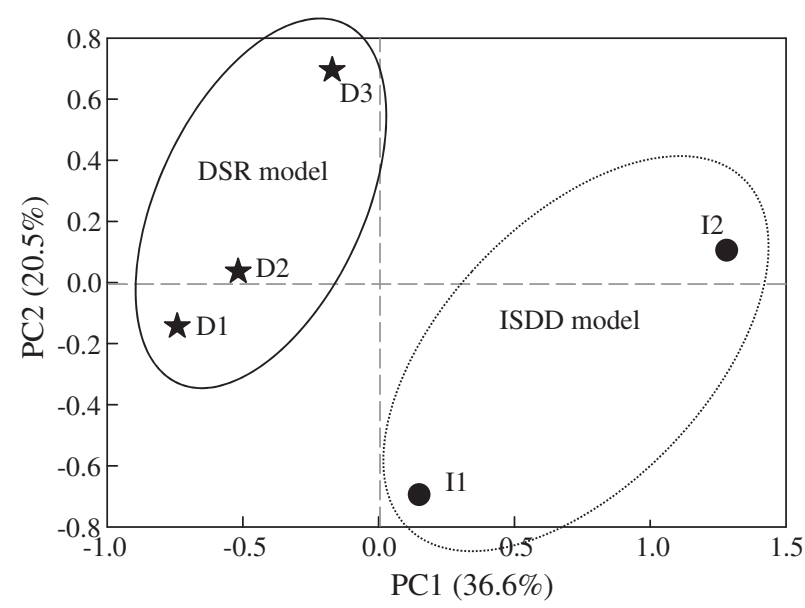

Fig. 2 - Principal component analysis (PCA) of communities from two models based on GeoChip data.

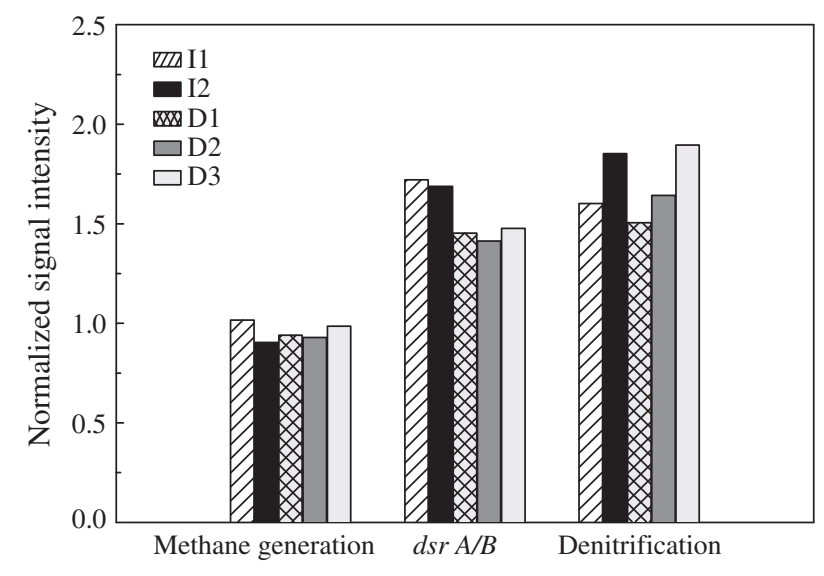

Fig. 3 - Relative abundance of selected functional gene categories in five samples revealed by GeoChip. The signal intensities were the average of detected individual gene sequences for each functional gene categories. dsrA/B: dissimilatory sulfite reduction genes (dsrA and $d s r B$ ).

Moreover, as well as SRB, notable difference of denitrifiers between two models was also observed in Fig. 5. Interestingly, some probes targeting from some typical NR-SOB were detected in all samples, including T. denitrificans, Sulfurimonas denitrificans (formerly known as Thiomicrospira denitrificans) and Paracoccus pantotrophus. The abundance of these species in each sample was showed in Fig. 6 . The relative abundance was higher in DSR model samples (D1, D2, D3) and lower in ISDD model samples (I1, I2). The highest relative abundance of these NR-SOB probes was detected in D3 sample. This finding indicates that NR-SOB might well acclimate and enrich step by step in DSR model.

\section{Discussion}

This study comprehensively assessed the performance of two theoretical models, ISDD and DSR models, and examined the microbial diversity and metabolic potential of functional community to better understand the biological role of functional groups under different operational conditions. Although the initial granules were obtained from same reactor, the functional diversity and structure of microbial communities of each sample varied. This could be attributed to the fact that the operational model was the predominant factor in shaping functional composition and structure of microbial communities. This phenomenon was also observed in other bioreactor (Liu et al., 2010). While in the same operational model, loading rate might be the major factor affecting microbial communities. Comparing two models, it is likely that DSR model had strong ability to enrich functional microbial diversity at high loading rate condition, while that ability in ISDD model was relatively poor (Fig. 1). This phenomenon in ISDD model may be addressed by two explanations. First, in the last period of ISDD model, the accumulation of sulfide ( $>150 \mathrm{mg} / \mathrm{L}$ ) produced by SRB is toxic to anaerobic bacteria (Lens et al., 1998). Second, both autotrophic and heterotrophic denitrifiers in the reactor had clearly inhibitive effect on SRB (Chen et al., 2008a). Moreover, decreased gene 


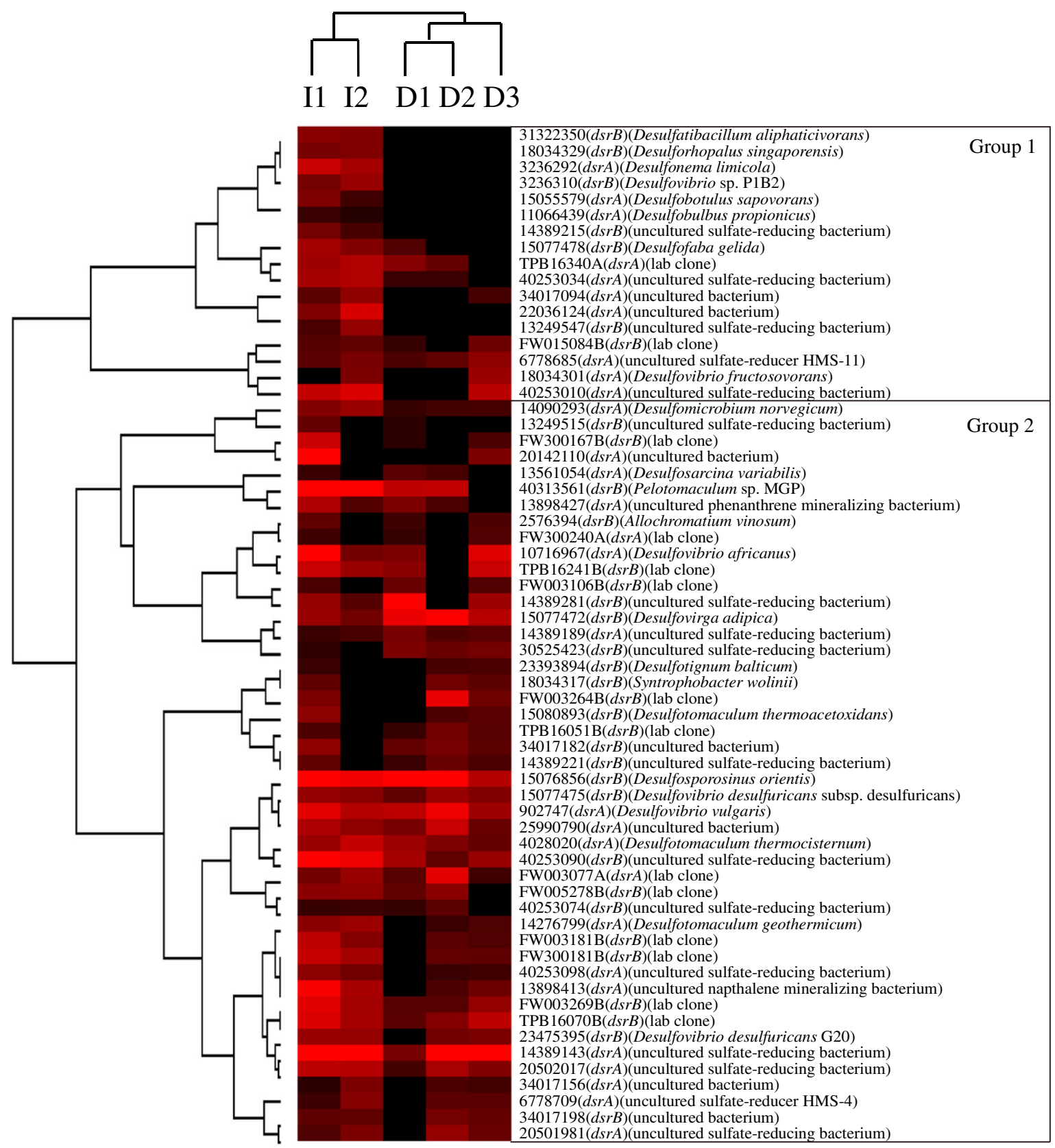

Fig. 4 - Hierarchical cluster analysis of the abundance of selected probes targeting dissimilatory sulfite reduction genes (dsrA and dsrB) across 5 samples. The figure was generated by CLUSTER and visualized with TREEVIEW. Red represents signal intensities above background and black represents signal intensities below background. Brighter red color represents higher signal intensities.

abundance does not necessarily correlate to a decreased functional role or vice versa.

The SRB was characterized by sulfate reduction genes (dsr $A$ and $d s r B$ ). Among $63 d s r A$ and $d s r B$ genes detected, 26 genes were derived from uncultured organisms, 14 genes were derived from lab clone species and 23 genes were derived from other cultured organisms (e.g., Desulfovibrio spp., Desulfobulbus spp., Desulfotomaculum spp., Desulfomicrobium sp., Desulfosporosinus sp.) (Fig. 4). This result showed that SRB is far more prevalent in two models than previously recognized (Chen et al., 2008a, 2008b). Comparing two models, the SRB was thriving in ISDD model, but declined in DSR model by substrate availability with sulfide-laden medium. In contrary to denitrification genes, the abundance of dsr genes slightly decreased in ISDD model with increase of loading rate (Fig. 3). It is possible that the SRB were inhibited by the high concentration of nitrate as previously reported (Greene et al., 2003; He et al., 2010; Hubert and Voordouw, 2007).

In recent years, there has been a significant increase in the knowledge on NR-SOB (An et al., 2010; De Gusseme et al., 2009; Zhang et al., 2009), which convert sulfide to element sulfur using nitrate as an electron acceptor. However, to date limited 


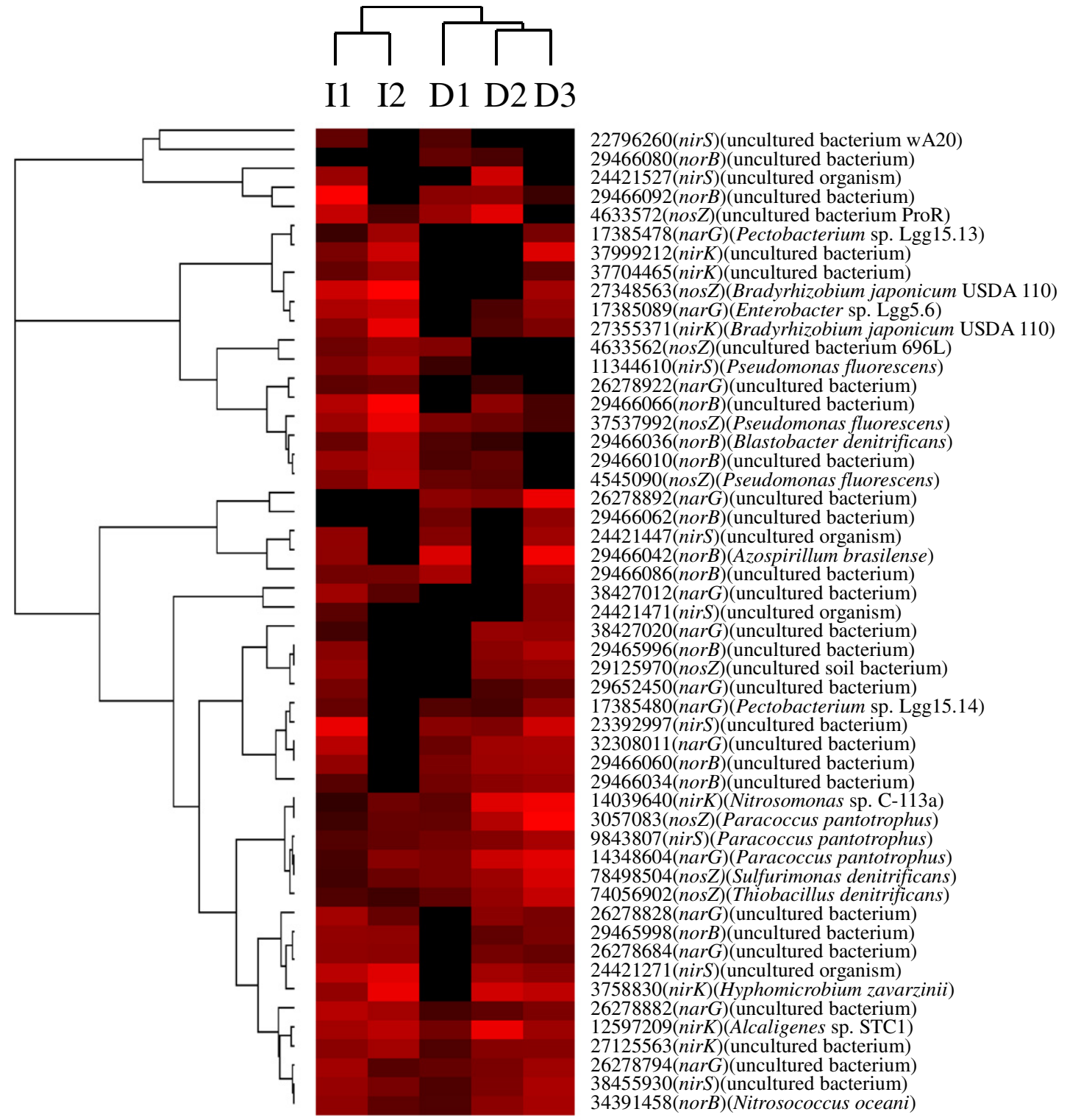

Fig. 5 - Hierarchical cluster analyses of functional genes involved in denitrification process.

research has been done on metabolic mechanism of NR-SOB in ISDD and DSR model. In this study, genes derive from NR-SOB microorganisms, including $\mathrm{T}$. denitrificans, $\mathrm{S}$. denitrificans and P. pantotrophus, were detected in both ISDD and DSR models. As previously reported, these species were widely present in oil field, petrochemical industry wastewater and sediment (Greene et al., 2003; Shao et al., 2010; Vaiopoulou et al., 2005; Zhang et al., 2009), and thought to play a critical role in sulfide control. Their abundance was changed with $S^{0}$ conversion rates observed in the two models (Table 1 and Fig. 6). This might potentially suggest that these species are crucial to $S^{0}$ recovery process. In DSR model, the NR-SOB was very likely acclimatized and stimulated by the increased concentration of nitrate and sulfide in influent medium as previously reported (De Gusseme et al., 2009; Garcia-de-Lomas et al., 2007). On the contrary, the sulfide concentration in ISDD model was relatively low in initial feeding wastewater and was greatly limited by sulfate reduction rate, which could effectively inhibit NR-SOB during this period. However, the heterotrophic denitrifiers become more prevalent by overpowering autotrophic rivals. Particularly under limited nitrate condition, the NR-SOB might be fully inhibited due to at a competitive disadvantage in ISDD model. This inference was also shown in Fig. 5 in which the abundances of genes derived from two heterotrophic denitrifiers, Blastobacter denitrificans (Hirsch and Müller, 1985) and Pseudomonas fluorescens (Al-Aoukaty et al., 1991), were higher in ISDD model while lower or miss-detected in DSR model. Thus, enrichment of NR-SOB may therefore be a more effective method to improve $S^{0}$ recovery efficiency of ISDD model. Overall, the results of GeoChip well explained the variations of performance achieved in two models. This will be important for further understanding the complex interaction of functional microbial groups which will contribute us to establish more direct linkage between microbial communities and reactor performance. 


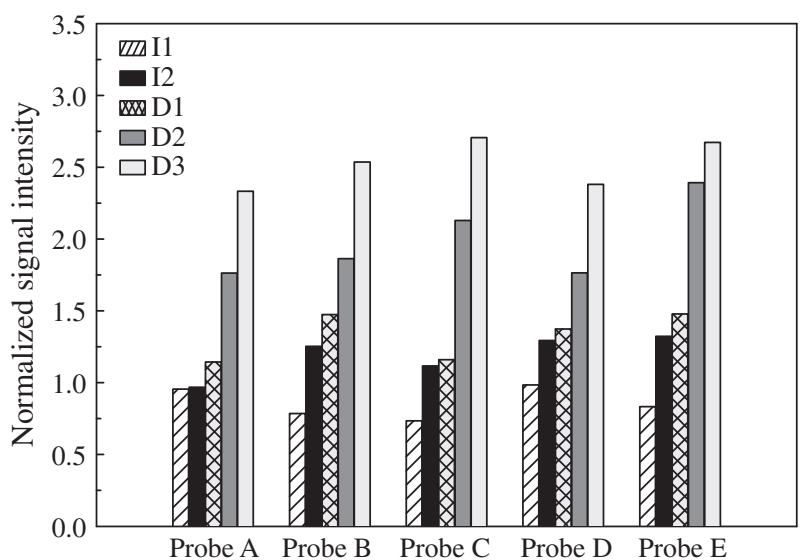

Fig. 6 - Relative abundance of denitrification genes derived from nitrate-reducing sulfide-oxidizing bacteria. Probe A: nosZ gene, derived from Thiobacillus denitrificans (74056902); Probe B: nosZ gene, derived from Sulfurimonas denitrificans (78498504); Probe C: nosZ gene, derived from Paracoccus pantotrophus (3057083); Probe D: nirS gene, derived from Paracoccus pantotrophus (9843807); Probe E: narG gene, derived from Paracoccus pantotrophus (14348604).

\section{Conclusions}

This work demonstrated that the $S^{0}$ conversion efficiency was higher in DSR model (91.1\%) than in ISDD model (25.6\%) when nitrogen and sulfur loading rates were 0.4 and $0.9 \mathrm{~kg} /\left(\mathrm{m}^{3} / \mathrm{day}\right)$, respectively. The functional diversity, structure and abundance of microbial community varied a lot between ISDD and DSR models. More importantly, functional genes targeting from several popular NR-SOB (e.g., T. denitrificans, S. denitrificans, $P$. pantotrophus) were detected across all samples. Their abundance was consistent with the change of $S^{0}$ conversion rates in two models.

\section{Acknowledgments}

This work was supported by the National High-Tech Research and Development Program (863) of China (No. 2011AA060904), and the National Natural Science Foundation of China (Nos. 51111140388, 51176037).

\section{R E F E R E N C E S}

Al-Aoukaty, A., Appanna, V.D., Huang, J., 1991. Exocellular and intracellular accumulation of lead in Pseudomonas fluorescens ATCC 13525 is mediated by the phosphate content of the growth medium. FEMS Microbiol. Lett. 83 (3), 283-290.

An, S., Tang, K., Nemati, M., 2010. Simultaneous biodesulphurization and denitrification using an oil reservoir microbial culture: effects of sulphide loading rate and sulphide to nitrate loading ratio. Water Res. 44 (5), 1531-1541.

Bai, S., Li, J., He, Z., Nostrand, J.D., Tian, Y., Lin, G., et al., 2013. GeoChip-based analysis of the functional gene diversity and metabolic potential of soil microbial communities of mangroves. Appl. Microbiol. Biotechnol. 97, 7035-7048.

Celis-García, L.B., González-Blanco, G., Meraz, M., 2008. Removal of sulfur inorganic compounds by a biofilm of sulfate reducing and sulfide oxidizing bacteria in a down-flow fluidized bed reactor. J. Chem. Technol. Biotechnol. 83 (3), 260-268.

Chen, C., Ren, N., Wang, A., Yu, Z., Lee, D.-J., 2008a. Microbial community of granules in expanded granular sludge bed reactor for simultaneous biological removal of sulfate, nitrate and lactate. Appl. Microbiol. Biotechnol. 79 (6), 1071-1077.

Chen, C., Ren, N., Wang, A., Yu, Z., Lee, D.-J., 2008b. Simultaneous biological removal of sulfur, nitrogen and carbon using EGSB reactor. Appl. Microbiol. Biotechnol. 78 (6), 1057-1063.

Chen, C., Wang, A., Ren, N., Kan, H., Lee, D.-J., 2008c. Biological breakdown of denitrifying sulfide removal process in high-rate expanded granular bed reactor. Appl. Microbiol. Biotechnol. 81 (4), 765-770.

Chen, C., Wang, A., Ren, N., Lee, D., Lai, J., 2009. High-rate denitrifying sulfide removal process in expanded granular sludge bed reactor. Bioresour. Technol. 100 (7), 2316-2319.

Cravo-Laureau, C., 2004. Desulfatibacillum aliphaticivorans gen. nov., sp. nov., an $n$-alkane- and n-alkene-degrading, sulfatereducing bacterium. Int. J. Syst. Evol. Microbiol. 54 (1), 77-83.

de Graaff, M., Klok, J.B.M., Bijmans, M.F.M., Muyzer, G., Janssen, A.J.H., 2012. Application of a 2-step process for the biological treatment of sulfidic spent caustics. Water Res. 46 (3), 723-730.

De Gusseme, B., De Schryver, P., De Cooman, M.l, Verbeken, K., Boeckx, P., Verstraete, W., et al., 2009. Nitrate-reducing, sulfide-oxidizing bacteria as microbial oxidants for rapid biological sulfide removal. FEMS Microbiol. Ecol. 67 (1), 151-161.

Garcia-de-Lomas, J., Corzo, A., Carmen Portillo, M., Gonzalez, J.M., Andrades, J.A., Saiz-Jimenez, C., et al., 2007. Nitrate stimulation of indigenous nitrate-reducing, sulfide-oxidising bacterial community in wastewater anaerobic biofilms. Water Res. 41 (14), 3121-3131.

Greene, E.A., Hubert, C., Nemati, M., Jenneman, G.E., Voordouw, G., 2003. Nitrite reductase activity of sulphate-reducing bacteria prevents their inhibition by nitrate-reducing, sulphide-oxidizing bacteria. Environ. Microbiol. 5 (7), 607-617.

He, Q., He, Z., Joyner, D.C., Joachimiak, M., Price, M.N., Yang, Z.K., et al., 2010. Impact of elevated nitrate on sulfate-reducing bacteria, a comparative study of Desulfovibrio vulgaris. ISME J. 4 (11), 1386-1397.

Hirsch, P., Müller, M., 1985. Blastobacter aggregatus sp. nov., Blastobacter capsulatus sp. nov., and Blastobacter denitrificans sp. nov., new budding bacteria from freshwater habitats. Syst. Appl. Microbiol. 6 (3), 281-286.

Hubert, C., Voordouw, G., 2007. Oil field souring control by nitrate-reducing Sulfurospirillum spp. that outcompete sulfate-reducing bacteria for organic electron donors. Appl. Environ. Microbiol. 73 (8), 2644-2652.

Klepac-Ceraj, V., Hayes, C.A., Gilhooly, W.P., Lyons, T.W., Kolter, R., Pearson, A., 2012. Microbial diversity under extreme euxinia, Mahoney Lake, Canada. Geobiology 10 (3), 223-235.

Lens, P.N.L., Van den Bosch, M.C., Hulshoff Pol, L.W., Lettinga, G. 1998. Effect of staging on volatile fatty acid degradation in a sulfidogenic granular sludge reactor. Water Res. 32 (4), 1178-1192.

Liang, Y., Li, G., Van Nostrand, J.D., He, Z., Wu, L., Deng, Y., et al., 2009. Microarray-based analysis of microbial functional diversity along an oil contamination gradient in oil field. FEMS Microbiol. Ecol. 70 (2), 324-333.

Liu, W.Z., Wang, A.J., Cheng, S.A., Logan, B.E., Yu, H., Deng, Y., et al., 2010. GeoChip-based functional gene analysis of anodophilic communities in microbial electrolysis cells under different operational modes. Environ. Sci. Technol. 44 (19), 7729-7735.

Manz, W., Eisenbrecher, M., Neu, T.R., Szewzyk, U., 1998. Abundance and spatial organization of Gram-negative 
sulfate-reducing bacteria in activated sludge investigated by in situ probing with specific 16S rRNA targeted oligonucleotides. FEMS Microbiol. Ecol. 25 (1), 43-61.

Rattanapan, C., Boonsawang, P., Kantachote, D., 2009. Removal of $\mathrm{H}_{2} \mathrm{~S}$ in down-flow GAC biofiltration using sulfide oxidizing bacteria from concentrated latex wastewater. Bioresour. Technol. 100 (1), 125-130.

Reyes-Avila, J., Razo-Flores, E.A., Gomez, J., 2004. Simultaneous biological removal of nitrogen, carbon and sulfur by denitrification. Water Res. 38 (14-15), 3313-3321.

Sahinkaya, E., Hasar, H., Kaksonen, A.H., Rittmann, B.E., 2011. Performance of a sulfide-oxidizing, sulfur-producing membrane biofilm reactor treating sulfide-containing bioreactor effluent. Environ. Sci. Technol. 45 (9), 4080-4087.

Shao, M.-F., Zhang, T., Fang, H.H., 2010. Sulfur-driven autotrophic denitrification: diversity, biochemistry, and engineering applications. Appl. Microbiol. Biotechnol. 88 (5), 1027-1042.

Vaiopoulou, E., Melidis, P., Aivasidis, A., 2005. Sulfide removal in wastewater from petrochemical industries by autotrophic denitrification. Water Res. 39 (17), 4101-4109.

Van Nostrand, J.D., Wu, W.-M., Wu, L., Deng, Y., Carley, J., Carroll, S., et al., 2009. GeoChip-based analysis of functional microbial communities during the reoxidation of a bioreduced uranium-contaminated aquifer. Environ. Microbiol. 11 (10), 2611-2626.

Waldron, P.J., Wu, L.Y., Van Nostrand, J.D., Schadt, C.W., He, Z.L., Watson, D.B., et al., 2009. Functional gene array-based analysis of microbial community structure in groundwaters with a gradient of contaminant levels. Environ. Sci. Technol. 43 (10), 3529-3534.
Wang, A.J., Du, D.Z., Ren, N.Q., Van Groenestijn, J., 2005. An innovative process of simultaneous desulfurization and denitrification by Thiobacillus denitrificans. J. Environ. Sci. Health Part A Toxic/Hazard. Subst. Environ. Eng. 40 (10), 1939-1949.

Wiessner, A., Kappelmeyer, U., Kuschk, P., Kästner, M., 2005. Sulphate reduction and the removal of carbon and ammonia in a laboratory-scale constructed wetland. Water Res. 39 (19), 4643-4650.

Wu, L., Liu, X., Schadt, C.W., Zhou, J., 2006. Microarray-based analysis of subnanogram quantities of microbial community DNAs by using whole-community genome amplification. Appl. Environ. Microbiol. 72 (7), 4931-4941.

Wu, L., Kellogg, L., Devol, A.H., Tiedje, J.M., Zhou, J., 2008. Microarray-based characterization of microbial community functional structure and heterogeneity in marine sediments from the Gulf of Mexico. Appl. Environ. Microbiol. 74 (14), 4516-4529.

Zhang, M., Zhang, T., Shao, M.F., Fang, H.H., 2009. Autotrophic denitrification in nitrate-induced marine sediment remediation and Sulfurimonas denitrificans-like bacteria. Chemosphere 76 (5), 677-682.

Zhou, J., Bruns, M.A., Tiedje, J.M., 1996. DNA recovery from soils of diverse composition. Appl. Environ. Microbiol. 62 (2), 316-322.

Zhou, J., Kang, S., Schadt, C.W., Garten, C.T., 2008. Spatial scaling of functional gene diversity across various microbial taxa. Proc. Natl. Acad. Sci. U. S. A. 105 (22), 7768-7773.

Zhou, J., He, Z., Nostrand, J.D.V., Wu, L., Deng, Y., 2010. Applying GeoChip analysis to disparate microbial communities. Microbe $5,60-65$

Zhou, J., Xue, K., Xie, J., Deng, Y., Wu, L., Cheng, X., et al., 2012. Microbial mediation of carbon-cycle feedbacks to climate warming. Nat. Clim. Chang. 2 (2), 106-110. 